\title{
WILEY
}

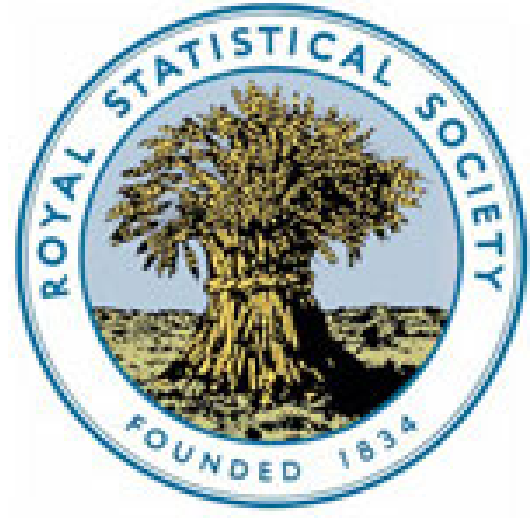

\section{The Enumeration of Paupers--A Correction}

Author(s): Charles Booth

Source: Journal of the Royal Statistical Society, Vol. 55, No. 2 (Jun., 1892), pp. 287-294

Published by: Wiley for the Royal Statistical Society

Stable URL: http://www.jstor.org/stable/2979594

Accessed: 25/06/2014 05:39

Your use of the JSTOR archive indicates your acceptance of the Terms \& Conditions of Use, available at http://www.jstor.org/page/info/about/policies/terms.jsp

JSTOR is a not-for-profit service that helps scholars, researchers, and students discover, use, and build upon a wide range of content in a trusted digital archive. We use information technology and tools to increase productivity and facilitate new forms of scholarship. For more information about JSTOR, please contact support@ jstor.org.

Wiley and Royal Statistical Society are collaborating with JSTOR to digitize, preserve and extend access to Journal of the Royal Statistical Society. 


\section{The Enumeration of Paupers- $a$ Correction.}

\section{By Charles Booth, Esq.}

THE following extracts from "Pauperism and the Endowment of " Old Age," the volume just issued by Mr. Charles Booth, refer to errors which occurred in the figures given in the Paper on the subject published in the December number of the Journal:- 1

\section{From Part I, chapter vi.}

"The figures, if they were in themselves correct, would show " that the paupers counted for six months were, thirty-five years " ago, rather less than two-and-a-half times the number on one "day. It is probable that this was then an exaggeration, and " would be still more so now.

" This probability is borne out by the evidence of a parlia" mentary return, made in 1881 at the instance of Mr. J. R. Hollond, " then nember for Brighton, which seems to have been entirely "overlooked and forgotten by those who have been content to "quote and requote the figures used by Mr. Dudley Baxter. This " return, which is signed by Mr. Purdy, as statistical secretary to "the Local Government Board, gives the 'number of persons " " relieved as paupers (exclusive of vagrants) during the half" " year ended with Lady-day, 1881, in each union county of "“ 'England,' and may be compared with the return of the number " in receipt of relief on the lst January in that year. The com" parison shows a total of $1,291,424$ for the six months, against " 803,303 on the single day, or an addition to the number on one " day of 6r per cent.

"The following table shows how the 6r.per cent. is distributed " between in-door and out-door relief (stating the lunatics separately " as in a different category, and assuming that 6 per cent. ${ }^{2}$ is for " them a sufficient percentage of addition):-

\begin{tabular}{|c|c|c|c|}
\hline & Counted lst January. & $\begin{array}{l}\text { Counted } \\
\text { for Six Months. }\end{array}$ & Percentage Addition. \\
\hline $\begin{array}{l}\text { Lunatics ................... } \\
\text { In-door poor ........ } \\
\text { Out-door , }\end{array}$ & $\begin{array}{r}62,954 \\
172,722 \\
567,450\end{array}$ & $\begin{array}{r}66,731 \\
299,788 \\
924,905\end{array}$ & $\left.\begin{array}{l}6 \text { p. ct. } \\
74 \stackrel{ }{63} "\end{array}\right\} 65^{\frac{1}{2}}$ p. ct. \\
\hline Total................. & 803,126 & $\mathrm{I}, 29 \mathrm{I}, 424$ & 61 p. ct. \\
\hline
\end{tabular}

Vol. liv, p. 621. 1891.

The actual percentage of increase at Stepney. 
"The difference between the 61 per cent. addition, according " to Mr. Hollond's return of 1881, and the 134 per cent. according " to Mr. Dudley Baxter's version of Mr. Purdy's figures in 1857, " may be accounted for in three ways-

“(1.) Error in the earlier count.

"(2.) Difference in the time of year chosen for the 'one " 'day' return.

“(3.) Changes in the character of pauperism since 1857.

"(1.) As to possible error in the earlier count, St. Pancras " furnishes some evidence. Both at Stepney and at St. Pancras " the officials have continued making up the half-year's figures in " the old way, and by the kindness of the guardians I have had "access to the books in which the returns are preserved. A " comparison of the figures in Mr. Hollond's return with the "figures in these books shows, at Stepney, an exact agreement, " but at St. Pancras, while the books show 24,048, the return gives " 20,61 8 as the true number. At St. Pancras, I understand, no " attempt was usually made to strike off duplicate entries due to " the passing of paupers from institution to institution, if indeed " re-entries in the same institution were allowed for, and thus " the current figures involved an error which had probably been " characteristic of many of the returns on which Mr. Purdy must " have based his figures in 1857 , but on which it seems he did not " entirely rely. At Stepney the workhouse system is more simple, " and exceptional care has been taken to avoid any duplication, " and thus the return made for Mr. Hollond contains exactly the " same figures as appear in their own books, and may be accepted " as correct.

" (2.) The effect of a different time of year is very evident. "The number in receipt of relief on the 1st of January is at " its largest, and consequently the addition to be made for "others relieved in the twelve months will be at its smallest. "Mr. Hollond's figures are compared with the 1st January. "Mr. Dudley Baxter's are compared with those on the lst of "July. The difference between the numbers in January and in "July is about ro per cent. Allowing for this difference, if we " take for Mr. Hollond's return the 1st July as the starting point, " in place of 61 per cent. we get 79 per cent.

"(3.) There have been many changes since 1857. Out-door " relief has been less loosely given; the proportion of the old has " undoubtedly increased, and an altered policy with regard to " children and the sick may have assisted in making the character " of pauperism generally more stable. 
"The difference is nevertheless so great between 6i per cent. " (or 79 per cent.) and 134 per cent., and the question so important, " that I am glad to know that a return to cover the twelve months " ending Lady-day, 1892, has been moved for, and will be made " by the Local Government Board. Meanwhile Mr. Hollond's " return represents the latest and best official evidence on the " subject.

"But both these percentages refer to a six months' count, and "give no positive information as to the numbers for a whole year. "We have to add something, but it is difficult to say how much; " and just as a good deal depends upon what day is chosen in " arriving at the percentage of increase for six months, so the " addition to be made for the second half-year will depend much " on which six months have been counted first.

"At Stepney, starting with those in receipt of relief at the " end of April, and working backwards, we find that we have to " add on the whole I 30 per cent. to reach the six months' total for " the winter half-year ending on Lady-day, and to the six months' " total we have to add 29 per cent. to give the year's total. At " Ipswich, comparing those relieved on 1st January with the whole " number relieved (also during the winter half-year), the addition " is found to be 92 per cent., and to the six months' total 40 per " cent. must be added to give that for twelve months."

"The number of paupers for six months and twelve months " compared is as follows :-

\begin{tabular}{|c|c|c|c|}
\hline \multirow{3}{*}{$\begin{array}{l}\text { Stepney } \\
\text { Ipswich }\end{array}$} & $\begin{array}{l}\text { Counted } \\
\text { on One Day. }\end{array}$ & $\begin{array}{l}\text { Counted for the } \\
\text { Winter Six Months. }\end{array}$ & $\begin{array}{c}\text { Counted } \\
\text { for Twelve Months. }\end{array}$ \\
\hline & \multirow[t]{2}{*}{$\begin{array}{r}\text { I,087 (1st May) } \\
895 \text { (1st Jan.) }\end{array}$} & $\mid \begin{array}{l}2,530 \text { or } 130 \% \text { additional } \\
1,723,92,\end{array}$ & $\begin{array}{l}3,259 \text { or } 200 \% \text { additional } \\
2,406,169,\end{array}$ \\
\hline & & Average, 112 per cent. & Average, 185 per cent. \\
\hline
\end{tabular}

"If we may venture to apply a similar rate of progress to " Mr. Hollond's six months' figures, we should have-number of "paupers for all England :-

\begin{tabular}{c|c|c}
\hline Counted on One Day. & Counted for Six Months. & Counted for Twelve Months. \\
\hline $740,172 *$ (1st January) & $1,224,693 *$ or $65 \frac{1}{2} \%$ addl. & $1,581,303$ or $110 \%$ addl. \\
\hline
\end{tabular}

* Lunatics deducted.

3 Lunatics are excluded from these figures, but no deduction has been made for deaths. 
"I am able to compare this estimate with actual returns from " Paddington and Ashby, as well as Stepney and Ipswich, but in " this comparison I have deducted the deaths that have occurred " amongst those relieved, for it is evident that those who die " during the year should not be included in an estimate of existing "pauperism. I assume that the dead as well as the living are " included in Mr. Hollond's return, and, guided by the facts at the " unions I have examined, I adjust the figures by assuming a " death-rate of 6 per cent. The table is arranged to show in-door " and out-door poor separately:-

A Iear'e Pauperism, excluding Lunatics and Vagrants, and deducting those who Died during the Year.

\begin{tabular}{|c|c|c|c|c|c|c|c|c|c|c|}
\hline \multirow[b]{2}{*}{ Parish. } & \multirow[b]{2}{*}{ Year. } & \multicolumn{3}{|c|}{ In-door. } & \multicolumn{3}{|c|}{ Out-door and Medical. } & \multicolumn{3}{|c|}{ Total. } \\
\hline & & $\begin{array}{c}\text { Number } \\
\text { on } \\
\text { One Day. }\end{array}$ & $\begin{array}{c}\text { Number } \\
\text { for } \\
\text { Twelve } \\
\text { Months. }\end{array}$ & $\begin{array}{c}\text { Per } \\
\text { Cent. of } \\
\text { In- } \\
\text { crease. }\end{array}$ & $\begin{array}{c}\text { Number } \\
\text { on } \\
\text { One Day. }\end{array}$ & $\begin{array}{c}\text { Number } \\
\text { for Twelve } \\
\text { Months. }\end{array}$ & $\begin{array}{c}\text { Per } \\
\text { Cent. ot } \\
\text { In- } \\
\text { crease. }\end{array}$ & $\begin{array}{l}\text { Number } \\
\text { on } \\
\text { One Day. }\end{array}$ & $\begin{array}{c}\text { Number } \\
\text { for Twelve } \\
\text { Months. }\end{array}$ & $\begin{array}{c}\text { Per } \\
\text { Cent. of } \\
\text { In- } \\
\text { crease. }\end{array}$ \\
\hline epney & 1889 & 925 & 1,905 & 106 & 162 & 1,142 & 637 & 1,087 & 3,047 & 182 \\
\hline xddington & $\begin{array}{c}\text { and } \\
\text { '91 } \\
\text { (mean) }\end{array}$ & $\mathrm{J}, 083$ & 2,478 & I 29 & 510 & 1,888 & 270 & 1,593 & 4,366 & 180 \\
\hline \multirow{3}{*}{$\begin{array}{l}\text { shbv-de }- \\
\text { la-Z̈ouch } \\
\text { swich ........ }\end{array}$} & \multirow{3}{*}{$\begin{array}{r}1889 \\
' 91\end{array}$} & 122 & 224 & 84 & 565 & 916 & 62 & 687 & 1,140 & 67 \\
\hline & & 290 & 568 & 96 & 605 & 1,737 & 187 & 895 & 2,305 & 158 \\
\hline & & 2,420 & 5,175 & 114 & 1,842 & 5,683 & 209 & 4,262 & 10,858 & 155 \\
\hline $\left.\begin{array}{l}\text { II England } \\
\text { estimated) }\end{array}\right\}$ & 1881 & 172,722 & 370,039 & I 14 & $5^{67,45^{\circ}}$ & $1,118,891$ & 97 & 740,172 & $1,488,930$ & 101 \\
\hline
\end{tabular}

“ This table shows in a very remarkable manner the more constant " character of country as compared with city pauperism, especially " as regards out-door relief; and, taking this into account, there " is nothing improbable in the estimated figures here given for " all England, which point to a probable addition of more than " 100 per cent. on the in-door, and rather less than roo per cent. " on the out-door, or on the average of about 100 per cent. all " round.

" On the information which I had before me when I wrote the " paper on this subject for the Royal Statistical Society last “ December, before seeing Mr. Hollond's 1881 return, I assumed " that for in-door pauperism an addition of 85 per cent., including "lunatics,.or 106 per cent. excluding them, might fairly be made, " but that for ont-door pauperism double this rate would not be " too much. This last assumption, though true of the unions I 
" had examined, and perhaps true of city pauperism generally, " is plainly not true of country pauperism, and consequently the " hypothetical figures I put forward at that time involved a con" siderable error. It now seems that, if we take the whole country, " the percentage to be added to obtain the annual figures for out" door pauperism is actually less than that needed for in-door " pauperism, and an analysis of $\mathrm{Mr}$. Hollond's return shows con" clusively that it is in the country districts, where out-relief is " most freely given, that it is also most stable in character. In " towns, and especially where out-relief is checked, there is usually " a great development of medical or other forms of temporary " assistance given to those in trouble; and as the people relieved " in this way vary from month to month, the total numbers on the " books are much swollen in the course of a year.

" The revised estimate which I now put forward of 100 per " cent. to be added on the whole, in-door and out-and probably " rather more than this rate in-door and rather less than this rate " out-door-differs very widely from the 3 or $3 \frac{1}{2}$ times laid down " by Mr. Mulhall and Mr. Baxter. It does not pretend to exact" ness, and should be used with some reserve pending the com"pletion of the present official inquiry."

\section{From Part II, chapter ii.}

"We have seen that for pauperism of all ages, excluding " lunatics, it is probably necessary to double the number relieved " on one day to arrive at the total number relieved in a year. But " as people grow older they become more settled in their habits, " and a larger and larger proportion of those who occasionally " accept relief either enter the house to stay there or receive " out-relief in a permanent form. The deduction for the deaths " occurring amongst those relieved during the year also chiefly " affects the old. The result is that instead of doubling the " number on one day, we do not need to add more than from " 30 to 50 per cent. This rate is considerably less than I esti" mated when addressing the Royal Statistical Society in Decem" ber last. The estimate made at that time was admittedly " supposititious; that now put forward is based on actual count " in five unions, and though still open to question, as the basis " is not broad enough for safety, is certainly nearer the truth "The following table gives the percentages for the five unions in " which an actual enumeration has been made:- 
Percentages to be added to the Number of Paupers, as Counted on One Day, to arrive at the Total Numbers for a Whole Year (Lunatics excluded and Deaths deducted).

\begin{tabular}{|c|c|c|c|c|c|c|c|c|}
\hline \multirow{2}{*}{ Union. } & \multicolumn{2}{|c|}{ Iu-door. } & \multicolumn{2}{|c|}{$\begin{array}{l}\text { Out-door } \\
\text { (Ordinary). }\end{array}$} & \multicolumn{2}{|c|}{ Medical. } & \multicolumn{2}{|c|}{ Combined. } \\
\hline & $\begin{array}{c}\text { All } \\
\text { Ages. }\end{array}$ & Over 65. & $\begin{array}{c}\text { All } \\
\text { Ages. }\end{array}$ & Orer 65. & $\begin{array}{c}\text { All } \\
\text { Ages. }\end{array}$ & Over 65. & $\begin{array}{l}\text { All } \\
\text { Ages. }\end{array}$ & Over 65. \\
\hline 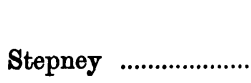 & $\begin{array}{c}\text { Per cnt. } \\
106 *\end{array}$ & $\begin{array}{c}\text { Per cnt. } \\
37\end{array}$ & $\begin{array}{c}\text { Per cnt. } \\
32\end{array}$ & $\begin{array}{c}\text { Per cut. } \\
\text { Nil }\end{array}$ & $\begin{array}{c}\text { Per cnt. } \\
657\end{array}$ & $\begin{array}{c}\text { Per cnt. } \\
361\end{array}$ & $\begin{array}{c}\text { Per cnt. } \\
182\end{array}$ & $\begin{array}{c}\text { Per cnt. } \\
69\end{array}$ \\
\hline Paddington................ & 129 & 23 & 65 & 11 & $I, 09 I$ & 508 & 180 & 32 \\
\hline Ipswich ....... & 96 & 32 & 93 & 23 & 1,256 & 1,860 & $15^{8}$ & 53 \\
\hline Bradfield................. \{ & $\begin{array}{c}\text { No } \\
\text { return }\end{array}$ & \} 45\{ & $\begin{array}{l}\text { No } \\
\text { return }\end{array}$ & \} 27\{ & $\begin{array}{l}\text { No } \\
\text { return }\end{array}$ & $\begin{array}{c}\text { No } \\
\text { return }\end{array}$ & $\begin{array}{l}\text { No } \\
\text { return }\end{array}$ & 38 \\
\hline Barton-upon-Irwell & $"$ & 23 & $"$ & $\mathrm{Nil}$ & $"$ & 300 & $"$ & $12 \dagger$ \\
\hline
\end{tabular}

* Division of Stepney :-Under 16, 42 per cent.; 16 to 60,308 per cent.; 60 to 65,60 per cent.; 65 and upwards, 37 per cent. $=106$ per cent.

+ There was a heavy mortality amongst the old at Barton. If deaths are not deducted, the percentage for in-door becomes 53 per cent., and for out-door 14 per cent., or in all combined 31 per cent.

" Guided by the actual percentages at the different ages shown " by count at Stepney, we may perhaps assume that the total " addition of 100 per cent. would be allotted as under to the " different ages :-

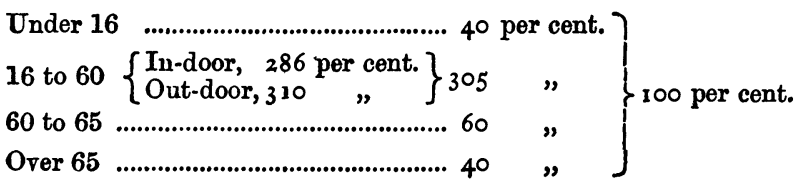

"Applying these percentages to the figures of pauperism on " one day, we are able to construct the following table. As these " figures do not pretend to accuracy, I treat in-door and out-door " alike, and do not attempt to distinguish between the sexes. It " is, however, probable that the out-door figures are rather over" stated, and we know that of those relieved outside the work" house a very large proportion are women. 
A Year's Pauperism, 1890-91 (excluding Lunatics and Vagrants).

\begin{tabular}{|c|c|c|c|c|c|}
\hline \multirow[b]{3}{*}{$\left.\begin{array}{c}\text { Number of paupers on 1st } \\
\text { July, } 1890^{*}\end{array}\right\}$} & \multicolumn{5}{|c|}{ In-door. } \\
\hline & Under 16. & $16-60$. & $60-65$. & Over 65. & Total. \\
\hline & 47,069 & 35,670 & 13,372 & 54,752 & 150,863 \\
\hline \multirow{2}{*}{$\left.\begin{array}{r}\text { Estimated additions for } \\
\text { twelve months } \ldots . . \ldots \ldots \ldots \ldots \ldots . . .\end{array}\right\}$} & $\begin{array}{r}40 \% \\
18,827\end{array}$ & $\begin{array}{r}286 \% \\
102,112\end{array}$ & $\begin{array}{l}60 \% \\
8,023\end{array}$ & $\begin{array}{r}40 \% \\
21,901\end{array}$ & $\begin{array}{r}100 \% \\
150,863\end{array}$ \\
\hline & 65,896 & 137,782 & 21,395 & 76,653 & 301,726 \\
\hline \multirow[b]{3}{*}{$\left.\begin{array}{c}\text { Number of paupers on 1st } \\
\text { July, } 1890^{*}\end{array}\right\}$} & \multicolumn{5}{|c|}{ Out-door. } \\
\hline & \multicolumn{3}{|c|}{ Under 16. $16-60}$. & Over 65. & Total. \\
\hline & 178,258 & 110,688 & 27,808 & 190,935 & 507,689 \\
\hline $\left.\begin{array}{r}\text { Estimated additions for } \\
\text { twelve months } \ldots . . . . . . . . . . .\end{array}\right\}$ & $\begin{array}{l}40 \% \\
71,303\end{array}$ & $\begin{array}{r}310 \% \\
343,326\end{array}$ & $\begin{array}{r}60 \% \\
16,686\end{array}$ & $\begin{array}{l}40 \% \\
76,374\end{array}$ & $\begin{array}{l}100 \% \\
507,689\end{array}$ \\
\hline 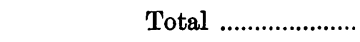 & 249,561 & 454,015 & 44,494 & $2 \dot{6} 7,309$ & $1,015,378$ \\
\hline
\end{tabular}

* Divided by ages according to Mr. Burt's return of 1st August, 1890.

In-door and Out-door (combined).

\begin{tabular}{|c|c|c|c|c|c|}
\hline & Under 16. & $16-60$ & $60-65$. & Over 65. & Total. \\
\hline $\left.\begin{array}{c}\text { Number of paupers on 1st } \\
\text { July, } 1890\end{array}\right\}$ & 225,327 & 146,358 & 41,180 & 245,687 & 658,552 \\
\hline $\left.\begin{array}{c}\text { Estimated additions for } \\
\text { twelve months } \ldots . . . . . . . . . . . .\end{array}\right\}$ & $\begin{array}{l}40 \% \\
90,130\end{array}$ & $\begin{array}{r}305 \% \\
445,438\end{array}$ & $\begin{array}{r}60 \% \\
24,709\end{array}$ & $\begin{array}{l}40 \% \\
98,275\end{array}$ & $\begin{array}{l}100 \% \\
658,552\end{array}$ \\
\hline Total & 315,457 & 591,796 & 65,889 & 343,962 & $1,317,104$ \\
\hline
\end{tabular}

"If, pending better information, this table may be taken to " represent the facts or a reasonable approximation to them, we " can go a step further, and show what proportion of our popula" tion at each age are to be accounted paupers.

\begin{tabular}{|c|c|c|c|}
\hline & Population. & Paupers.* & Ratio to Population. \\
\hline $\begin{array}{l}\text { Under } 16 \ldots . . . . . . . \\
16-60 \ldots \ldots \ldots . . . . . . \\
60-65 \ldots \ldots \ldots \ldots . . . . . \\
\text { Over } 65\end{array}$ & $\begin{array}{r}11,144,021 \\
15,722,273 \\
812,028 \\
1,322,696\end{array}$ & $\begin{array}{r}315,457 \\
591,796 \\
65,889 \\
343,962\end{array}$ & $\begin{array}{l}\text { Per cnt. } \\
2 \cdot 8 \\
3 \cdot 8 \\
8 \cdot 1 \\
25 \cdot 9\end{array}$ \\
\hline Total .......... & $29,001,018$ & $1,317,104$ & 4.5 \\
\hline
\end{tabular}

* Pauper lunatics excluded. 
"When the results of the promised inquiry are published by " the Local Government Board we shall know what degree of error " is shown by the figures given above. It may meanwhile be " accepted as probable that the ratio of paupers to population, if " on the average it is $4 \frac{1}{2}$ per cent., will be for those from 16 to 60 " (the naturally self-supporting years of life) less than 4 per cent., " but that for those between 60 and 65 the rate will rise to about " 8 per cent., while for those over 65 it is probably more than " 25 per cent." 